\title{
Federal and Local Electric Power in the Central Valley: Coordination or Duplication?
}

\author{
William B. Kuder*
}

\begin{abstract}
The Central Valley project is essentially a water conservation project. Its primary purposes are to control salinity in the fertile delta area and to transport excess water from the Sacramento Valley into the upper reaches of the San Joaquin Valley and to other areas where local supplies are not sufficient to meet the needs for irrigation and other uses.
\end{abstract}

Power is generated at Shasta and Keswick dams as an incident to the storage and release of water. Revenue from the sale of power is intended to aid and assist financially the water features of the project. The greater the net power revenue, the lower will be the cost of water to farmers and others.

The purpose of electric power in the Central Valley project was first declared by Congress in the Rivers and Harbors Act of 1937, Section 2 of which reauthorized the project and transferred it from the Secretary of War to the Secretary of the Interior. ${ }^{1}$

"Generation and sale of electric energy" are authorized "as a means of financially aiding and assisting" the water features of the project. Project reservoirs are to be "used, first, for river regulation, improvement of navigation, and flood control; second, for irrigation and dounestic uses; and, third, for power."

How this power shall be marketed presents a question of vital concern not only to California but to the entire nation. For the alleged purpose of disposing of project power, the Bureau of Reclamation proposes to construct a huge federal power system in northern and central California, consisting of hundreds of miles of transmission lines, substations and a large steam-electric generating plant. The cost of these facilities would exceed $\$ 80,000,000$. The area which the Bureau proposes to serve is now completely served by the interconnected system of Pacific Gas and Electric Company.

* Member of the San Francisco Bar; Assuciate Attorney, Pacific Gas and Electric Company.

1 50 STaT. 844, 850 (1937). 
The Company recognizes the need for conserving the waters of California and fully supports the policy of constructing sound reclamation and flood control projects. Early in the history of the Central Valley project the Company offered to coordinate the operation of the Shasta and Keswick plants with the Company's widespread power system. Such coordination would give project power its greatest value, make possible minimum charges for irrigation water, and result in the least burden on taxpayers, both local and federal.

\section{COORDINATED POWER OPERATION IN CALIFORNIA}

Coordination of interconnected hydroelectric and steam-electric generating plants to serve continuously growing demands withm a large region has been the key to providing low cost power in California. Prior to 1899 isolated hydro and steam plants ${ }^{2}$ served small separate markets in their immediate vicinity. In that year the Folsom plant on the American River and the Colgate plant on the Yuba River were interconnected with a steam plant at the City of Sacramento to serve adjacent areas.

This proved later to be an occurrence of tremendous importance, for such a tying together of hydroelectric plants and a steam plant to supply light to cities and to serve industry and agriculture with power, established the principles:

First: that advantage could be taken of the diversity which exists in stream flow;

Second: that a steam reserve furnished the desired continuity to hydroelectric service; and

Third: that pooling of a regional demand, which varied daily, seasonly, geographically and with character of energy usage, resulted in economy, owing to the greater number of hours which a given plant capacity could be effectively operated. ${ }^{3}$

At one time there were a large number of operating companies in northern and central California. Some of these companies operated duplicating facilities in competition with each other. Under the authority of the California Public Utilities Commission, established in

2 The first central station steam plant in the United States was built in San Francisco in 1879. Beginning about 1885 other small generating units were constructed in San Francisco and Oakland. By 1895 a total of nearly 6000 kilowatts were in operation. The first hydro plant in northern California was the 1500-kilowatt Folsom plant, constructed in 1895 and still in operation.

${ }^{3}$ A. H. Markwart (formerly vice-president in charge of Engineering, Pacific Gas and Electric Company), Power in California, Journal of the Franklin Institute, August, 1927, p. 156. 
1911, the numerous local electric systems were integrated into a few large regional systems. These systems have served the public with greater dependability and at rates which have progressively declined as more of the benefits inherent in coordinated operation were realized.

The regional system of Pacific Gas and Electric Company is coordinated with other power sources. ${ }^{4}$ As a public utility, the Company has the obligation of serving the power demands of the area. It experienced difficulties in serving these demands immediately after World Wars I and II only as a result of war-time curtailment of construction. ${ }^{5}$ All power requirements of the area are now being fully met by the Company, and its reserve margins depleted during the war are reestablished. ${ }^{6}$

\section{THE COMPANY AIDS WATER CONSERVATION IN CALIFORNIA}

The Coinpany has constructed many reservoirs in the Sierra Nevada for development of water power, and the water thus conserved has been used for irrigation in the Sacramento and San Joaquin Valleys. The Company has long followed a policy of cooperating with the federal government, cities, irrigation districts and other governmental agencies in the development and storage of water. This is not a new policy, but dates back to the early 1920's when the major irrigation district projects in California were started.

The Company is purchasing power or water for the production of power from the East Bay Municipal Utility District and from the Merced, Nevada, Modesto, Turlock, Oakdale, South San Joaquin and Thermalito Irrigation Districts. For such purposes the Company in 1949 paid to these public agencies more than $\$ 1,300,000$. The Company provided an assured market for the power developed at these public projects and thereby aided in financing their construction.

4 The Company owns and operates 58 hydroelectric plants interconnected with 16 steam-electric plants and the plants of several other agencies.

5 Since 1937, when construction on the Central Valley project commenced, the Company has constructed power facilities aggregating 1,300,000 kilowatts, about three times the 450,000-kilowatt capacity of the Shasta and Keswick plants of the Central Valley project. By the end of 1951, the Company will have installed another 500,000 kilowatts at its Moss Landing and Contra Costa steam plants.

6 The highest peak demand on record in the Company's service area was $2,519,000$ kilowatts on July 25,1950 . The Company met this demand with 476,000 kilowatts to spare, a margin of $19 \%$. Of the total generating capacity available in the area, $83 \%$ was in company plants, and $17 \%$ in the plants of the Central Valley project and other producers, including irrigation districts. 
THE COMPANY PROVIDES A MARKET FOR CENTRAL VALLEY PROJECT POWER

The Company has followed this policy of cooperation with respect to Shasta and Keswick power. In 1937, before construction on the project was started, the Company offered to coordinate its facilities with those of the Central Valley project. ${ }^{7}$ Later, when the magnitude of the project became known, the Company offered to make a market for all project power as rapidly as it could be developed, to purchase this power either at Shasta dam or at the Company's nearby Shasta substation, and to pay a price equal to the value this power would have if "firmed" 8 by an independent steam plant. In case any difference should arise as to price, the Company offered to submit the issue to the Federal Power Commission or to the California Public Utilities Commission for final decision. To reserve a market for project power when it was expected to become available, the Company as early as 1936 entered into a contract to purchase power on a temporary basis from Southern California Edison Company, Ltd. This contract was later terminated as Shasta power became available.

The Company's offers of cooperation met with no success until the Senate Appropriations Committee in May 1942 recommended that "the Secretary of the Interior and the Pacific Gas and Electric Company immediately enter into a contract" for marketing project power "for the duration of the war and a reasonable time thereafter." P Pursuant to this recommendation, such a contract was executed September 23, 1943 and ran until December 31, 1948. Under this contract the Company took delivery at its Shasta substation of all the power pro-

i On February 11, 1937, James B. Black, president of the Company, made such an offer in a letter to tbe State Director of Public Works in which he set forth the Company's position as follows:

"It is and has been the fixed policy of our Company to aid and cooperate in the development of all worthy public projects which mean the building and growth of California. As California grows, so will our Company grow and benefit. We recognize the desirability and the necessity of conserving and putting to maximum beneficial use the waters of the State and we are anxious to assist in every possible way the final realization of this worthy objective."

8 In an independent system, the Bureau would construct a large steam plant to provide energy at times when the output of Bureau bydro plants was deficient by reason of low water supply. Where power is delivered to the Company, such deficiency is supplied by operating existing Company plants for longer periods than they would otherwise operate.

D Sen. Rep. No. 1380, 77th Cong., 2d Sess. 2, 3 (1942). 
duced at the project. The price paid for the power was set by the Bureau. ${ }^{10}$

On January 1,1949 , the Company entered into a day-to-day agreement with the Bureau under which the Company is obligated to take and pay for all the power capacity and energy which the Bureau declares to be available. This power is delivered to the Company at Shasta substation. Payments are made at the Bureau's interim or so-called "postage stamp" rate schedule which the Bureau offers throughout the Central Valley, even at a distance of two hundred miles or more from Shasta dam. ${ }^{11}$

The Company also agreed in this contract to deliver power to the Bureau for project uses on an exchange basis, such deliveries to be made to the Bureau's Contra Costa canal transmission line, to its facilities at the Tracy pumping plant location and to its facilities at Friant dam. For each kilowatt-hour so delivered, the Bureau furnishes the Company in exchange one kilowatt-hour at Shasta substation and, in addition, pays the Company one mill per kilowatt-hour as compensation for the exchange service. Under this arrangement the cost of power for project pumping plants would never be more than the cost of such power delivered over a fully-loaded, tax-free Government line, and for many years will be only a fraction of that cost. The Company has offered many times to extend this arrangement to all project pumping plants and other project uses.

The Company sells project power through its system at rates approved by the California Public Utilities Commission. Thus rates at both ends are determined not by the Company but by federal and state agencies. ${ }^{12}$

10 Harold Ickes, then Secretary of the Interior, testified in 1945 before the House Committee on Appropriations that this contract "provides a satisfactory financial return to the Umited States." Hearings before Committee on Appropriations on H.R. 4679, 78th Cong., 2d Sess. 42 (1945). H. W. Bashore, then Commissioner of Reclamation, said that the price paid by the Company was "a fair price to all parties concerned." $I d$. at 646. The rate was $\$ 10.00$ per kilowatt per year plus 1.5 mills per kilowatt-hour.

11 With sale near the dam at the "postage stamp rate," the net return to the project is increased by saving the amount of the annual cost of a transmission system and the value of the power otherwise lost in transmission.

12 Last year the Company paid an average of 5.1 mills for Shasta power, which is about five times what the Bureau charges the Bonneville Power Administration for Grand Coulee power. Under the day-to-day agreement, the rate is equivalent to $\$ 13.00$ per kilowatt per year plus 1.9 mills per kilowatt-hour. The Central Valley project in fiscal year 1949 produced less than $9 \%$ of the total power sold on all Bureau projects; but the returns from the Company equalled more than $20 \%$ of the Bureau's total power revenues. DEPARTMENT OF THE INTERTOR, ANNUAC, REPORT, 1949, p. 51. 
From 1944 to April 1950 the Bureau received a total revenue from the project of $\$ 28,711,426$, of which $\$ 2,168,927$ came from the sale of water and $\$ 26,359,150$ came from the sale of power. After paying operating, maintenance and replacement charges, $\$ 22,516,445$ was returned to the United States Treasury. This high net return is due entirely to the fact that the power has been sold to the Company near the dam. Had it been sold over Government transmission lines, the return to the treasury would have been much less. Gross revenue would have been reduced by losses in transmission. Annual expenses would have been increased by the cost of operating and maintaining the additional and unnecessary facilities which the Bureau seeks to construct.

The benefits of this cooperative program accrue to water users, power consumers and taxpayers. The California Public Utilities Commission has effectively regulated the rates, financing and operations of public utilities in this state since 1911. Under such regulation, payments made by the Company to the Bureau for project power are entered as an operating expense on the Company's books. The Company can make no profit on the power it purchases. All that it is allowed to earn is a fair return on the investment it makes itself in facilities used and useful in service to the public. Any benefits from purchased power must be passed on to power consumers in the form of lower electric rates.

\section{FEDERAL DUPLICATION OF LOCAI FACIIITIES}

Notwithstanding the Company's repeated offers of cooperation, the Bureau has attempted during the past ten years to set up a duplicating commercial power system. It has sought appropriations for transmission lines, substations and a steam plant which are wholly unnecessary.

\section{Transmission Lines}

The Bureau has proposed three main transmission limes: a 230kilovolt line east of the Sacramento River from Shasta dam to Tracy, and two 230-kilovolt lines west of the river between the same points.

The Bureau began its transmission system in 1943. In that year it requested funds for a lime from Shasta dain to connect with the Company's system at Oroville. Congress, following the recommendation of the House Committee on Appropriations, ${ }^{13}$ denied these funds but allowed $\$ 400,000$ which was earmarked for a "transmission line 
to Shasta Substation" only. ${ }^{14}$ Mr. Ickes, then Secretary of the Interior, ignored this announced intent of Congress and built the line through to Oroville out of "unexpended balances." The next year Congress refused to appropriate any funds for transmission facilities and specifically reallocated "the unexpended balance heretofore determined to be available for construction of transmission lines" to "other construction features of the project."15

In 1945 the House Committee on Appropriations stated in its report:

There is no unserved market in the area. The proposed steam plant and transmission system would duplicate if not destroy existing taxpaying facilities and take much valuable property off the tax rolls to the detriment of many towns and counties in the State of California. ${ }^{16}$

No additional funds were appropriated for transmission lines until a deficiency bill was enacted late in December 1945. This and subsequent acts authorized the east-side line to be constructed through to Tracy only for the purpose of serving project pumps and other project uses. In 1948, when denying funds for commercial transmission lines, the House Appropriations Committee said:

It is unsound and against the principles of our form of government to appropriate Government funds for the construction of transmission lines, switchyards, substations, and incidental facilities where private capital is prepared to provide them. ${ }^{17}$

However, in 1949 Congress departed from this statement of principle and appropriated $\$ 2,000,000$ to begin construction of the westside lines. ${ }^{18}$ These lines would parallel four lines of the Company that now carry in addition to other power the output of the Shasta and Keswick plants. At most places the Bureau's lines are less than half a

1457 STAT. 451,476 (1943).

1558 STAT. 463, 490 (1944).

16 H. R. REP. No. 437, 79th Cong., 1st Sess. 18 (1945). The Company pays taxes in 48 of the 58 counties of the State. In a number of counties it pays more than $50 \%$ of the total taxes collected for county purposes. Taxes accrued for 1949 were: Federal, $\$ 13,316,206$; State and local, $\$ 26,962,102$. Since 1940 , to and including 1949 , a period of 10 years, the Company has paid more than $\$ 183,000,000$ into the federal treasury in taxes. In the same period it paid in State and local taxes more than $\$ 166,000.000$.

17 H. R. REP. No. 2038, 80th Cong., 2d Sess. 20 (1948).

18 Appropriations for these lines had previously been denied by Congress in 1942, 1945 (twice), 1946, 1947 and 1948. This year Congress allowed $\$ 6,100,000$. 
mile from the Company's lines. The west-side hines are not required to supply power to assure dependable service to the Tracy pumps. The ultimate requirements of these pumps years hence will be only 120,000 kilowatts, which can be fully supplied by the Bureau's east-side line with its capacity of 150,000 kilowatts. Existing Company lines are available to the Bureau to supply standby for the pumps as part of the Company's exchange service.

The Bureau also has attempted, so far without success, to obtain appropriations for a 115-kilovolt line from Keswick to Tracy. ${ }^{19}$ This line would follow a zig-zag route down the Sacramento Valley. Its purpose is not to serve any reclamation requirement, but to start a duplicating power network designed to put government power into cities and towns in the Sacramento Valley and into the delta area, already served by the Company.

The Bureau has tried for years to take away from the Company cities and towns which own their electric distribution systems, as well as various irrigation, drainage, and other districts which purchase their power requirements from the Company. All these municipalities and districts have been customers of the Company or its predecessors for thirty years or more. In 1945 the Bureau solicited the cities of Biggs, Gridley, Lodi, Redding and Roseville to enter into agreements to purchase power from the Bureau. However, in the latter part of 1945 , all these cities except Roseville ${ }^{20}$ entered into agreements to purchase their power from the Company for a 5-year period, and in 1949 renewed the agreements for an additional five years. At that time the Bureau again pressed Redding for a contract, but at a special election on the question whether the City should purchase power from the Company or the Bureau, a majority voted in favor of renewing the contract with the Company. Recently Roseville entered into an agreement to purchase its power from the Company for five years.

\section{Steam Plant}

The Bureau for many years has unsuccessfully attempted to obtain funds to construct a steam-electric generating plant estimated to have a capacity of about 240,000 kilowatts and to cost approximately

19 Funds were denied by Congress in 1945 (twice), 1946, 1947, 1948 and 1949. Congress has denied this year's request for $\$ 300,000$.

20 Congress has made no appropriations for facilities to serve Roseville. Funds were denied in 1945, 1946, 1947, 1948 and 1949. Congress has denied this year's request for $\$ 650,000$. 
$\$ 33,000,000$. The plant would be located in the Sacramento River delta. ${ }^{21}$

Construction of a steam plant is wholly outside the purposes of the project as defined by Congress. The project was originally authorized by the President pursuant to the Emergency Relief Appropriation Act of $1935 .^{22}$ Since irrigation was involved, the Reclamation Acts of $1910^{23}$ and $1924^{24}$ required the Secretary of the Interior to define the scope of the project in a feasibility report. This he did by letter to the President dated November 26, 1935 in which he enumerated the dams, conduits and all other facilities comprising the project. A steam plant was not included. ${ }^{25}$

The reauthorizing act of $1937^{26}$ contains no reference to a steam plant and provides that "the provisions of the reclamation law ... shall govern" the construction of power plants on the project. ${ }^{27}$ The reclamation law ${ }^{28}$ authorizes hydroelectric power generation only at reclamation dams as an incident to the operation of project water works. Steam plants are not authorized and would be a departure from long-standing reclamation policy.

In 1941, when the Bureau for the first time requested funds for a project steam plant, the House Appropriations Committee declared in its report:

The main purposes of the Central Valley Project as originally authorized was [sic] for reclamation and flood control and other development must be regarded as of secondary importance. Also, the

27. Funds for construction of this plant were denied by Congress in 1941, 1942 and in 1949. Congress has denied this year's request for $\$ 2,000,000$. An allowance of $\$ 200,000$ was made in 1942 for preliminary engineering studies only. Further funds for such studies were denied in 1945 and in 1948.

2249 STAT. 115 (1935).

23 Sec. 4, 36 STAT. 835 (1910), 43 U.S.C. $\$ 911$ (1946).

24 Sec. 4 b, 43 Stat. 702 (1924), 43 U.S. C. $\$ 412$ (1946).

25 In 1947 the Secretary of the Interior, in a report to Congress concerning project costs, included a delta stean plant as one of the principal features for which he requested approval of an allocation of costs. H. R. Doc. No. 146, 80th Cong., 1st Sess. 2 (1947). Congress has taken no action on this report. Such allocation is ineffective until Congress approves. Sec. 7b, 53 Star. 1187, 1192 (1939) as amended, 43 U.S. C. $\$ 485 f$ (1946).

${ }^{26}$ Supra note 1.

$2 \pi$ The project was again reauthorized by the Act of October 17, 1940, 54 STAT. 1198 (1940). This act does not mention a steam plant, and emphasizes the reclamation purposes of the project by providing that project water distribution systems must be constructed "under the provisions of the Federal reclamation laws."

2832 STAT. 388 (1902), as amended, 43 U.S. C. $\$ 391$ (1946). 
proposed steam plant is the first departure from water power development contemplated in connection with a reclamation project. ${ }^{29}$

A steam plant has no proper place in the development of the Central Valley as a water project. It is not needed to furnish standby for the Tracy pumps or to firm up commercial power. The Company's steam and hydro plants are already supporting all the project's dependable hydro capacity. The Company is paying for this power at firm power rates. Furthermore, the Company has long offered to furnish standby service for the Tracy pumps without charge as part of its exchange service. Any standby power used by the pumps would be returned in kmd. The Company has provided such service for the project pumps on the Contra Costa canal ever since they were placed in operation. More than that, the Company has always offered to "make firm" any power that the Bureau may sell to public agencies, and to do this at a cost no greater than if such power were firmed by a project steam plant. In short, the Company's many steam and hydro plants, operated in coordination with the Bureau's Shasta and Keswick plants, are already firming up the project's hydro power and giving it the maximum value. A project steam plant, no matter how large, could do no more.

\section{Cost of Bureau's Commercial System}

Construction of the Bureau's proposed commercial electric system ${ }^{30}$ would cost in excess of $\$ 80,000,000$. Even if fully loaded, this system would cost water users and federal taxpayers $\$ 5,000,000^{31}$ a year more than if the power continued to be sold to the Company at Shasta substation.

The Bureau has never submitted a detailed statement showing the financial results expected under its power plan on the basis of present construction and operating costs. If such a statement were submitted it would show that, compared with the present method of sale, the Bureau's power plan would (1) require water users to pay $\$ 140,000$,000 more for water during the period of repayment, ${ }^{32}$ (2) require

29 H. R. REP. No. 476, 77th Cong., 1st Sess. 13 (1941).

30 West-side lines, Keswick-Tracy line, the steam plant and related commercial power facilities.

31 Operation, maintenance and amortization of the cost of the transmission system over a repayment period of 50 years, with interest at $3 \%$, would be $\$ 3,000,000$ per year. Cost of steam power from the Bureau's proposed plant would be $\$ 2,000,000$ per year more than revenue from the sale of such power.

$32 \$ 3.50$ per acre-foot for Class I water and $\$ 1.50$ per acre-foot for Class II water at the canal side. If the Bureau's commercial power system is not built, Class I water 
$\$ 80,000,000$ more from federal taxpayers in interest charges over the same period, and (3) require project power rates to be raised to at least the level of existing Company rates, which include nearly 20 per cent in taxes.

\section{KINGS RIVER POWER DEVELOPMENT}

Another example of the efforts of the Bureau to construct a commercial power system under the guise of reclamation is provided by the pending Kings River controversy.

The Company owns the Balch power project, which was constructed on this river 25 years ago under Federal Power Commission license. In January 1948 the Company applied to the Commission for licenses to enlarge this plant and construct three new plants on the river above Pine Flat reservoir, with total additional capacity of 243,000 kilowatts. The Fresno Irrigation District, for itself and 19 other Kings River water users' organizations, also had applied to the Commission for a preliminary permit for power developments on the river.

The Bureau of Reclamation opposed both applications on the ground that it desired to acquire the Company's existing Balch plant and construct a new single-purpose power development as a part of the Central Valley project. The Bureau plans to enlarge the Balch plant and construct two power plants above Pine Flat reservoir with total additional capacity of 70,500 kilowatts. Although the Company's project would develop more than three times as much additional capacity on this stretch of the river as that proposed by the Bureau, the estimated cost of each development was approximately $\$ 70,000,000$.

After extensive hearings the Commission rejected the Bureau's contentions in November 1949. It found that the developments proposed by local agencies would best serve the public interest and authorized licenses for the Company's development and a preliminary permit for a plant proposed by the irrigation district at Pine Flat dam. ${ }^{23}$ A rehearing, granted at the request of the Secretary of the

could be sold for $\$ 1.50$, Class II water for less than $\$ 0.75$, and power could be sold at the present Bureau rate.

33 In the Matters of Fresno Irrigation District, Project No. 1925, and Pacific Gas and Electric Company, Projects Nos. 175 and 1988, Federal Power Commission Opinion No. 183, November 10, 1949. Since Pine Flat reservoir would provide reregulation for upstream power releases, the Commission required the Coinpany to compensate the United States for such use. The Commission also required the Company to enter into an agreement with local irrigation interests providing for the use by the Company of Kings River water for power purposes. 
Interior, was held in March 1950. No decision has been rendered by the Commission on rehearing. ${ }^{34}$

None of the dams proposed above Pine Flat reservoir would regulate water for navigation, irrigation or flood control. They are not reclamation dams. Their sole purpose is to produce electric power. ${ }^{35}$ Congress has never authorized the Bureau to construct any singlepurpose power development, either in the reclamation law or in acts authorizing specific projects. ${ }^{36}$ It has authorized the Bureau to construct power plants only where they are incidental to inultipurpose dams. Authorization of the Bureau's upper Kings River power project would be a major departure from the reclamation policy Congress has consistently followed for fifty years.

34 There are five bills before Congress to reauthorize the Central Valley project to include the Bureau's Kings River development: H. R. 5264, 81st Cong., 1st Sess. (1949), H. R. 6919, 81st Cong., 2d Sess. (1950), H. R. 8303, 81st Cong., 2d Sess. (1950), H. R. 8885, 81st Cong., 2d Sess. (1950) and H. R. 9632, 81st Cong., 2d Sess. (1950). In March, May and August 1950, the Subcommittee on Irrigation and Reclamation of the House Committee on Public Lands held learings on the first four bills but issued no report.

35 Representatives of the Bureau testified at the Federal Power Commission hearings that the Kings River project will not develop any water for export to other watersheds (Tr. 693, 694); nor will Central Valley project water be available for the Kings River area (Tr. 819, 820,874, 875, 884, 885). They also admitted that construction of the Company's project would not interfere in any way with the Central Valley project (Tr. 859, 928). The staff of the Federal Power Commission pointed out that "the only physical coordination proposed by the Secretary between the Kings River developments and the Central Valley Project is the interconnection of electric transmission lines" (Reply Brief on Rehearing, p. 29). The Bureau's plans were submitted to the State of California for its views and recommendations in accordance with the provisions of Section 1 of the Flood Control Act of 1944 (58 STat. 887, 888). On March 20, 1950, the State report was transmitted by the Seeretary of the Interior to the Speaker of the House. H. R. Doc. No. 537, 81st Cong., 2d Sess. 1 (1950). The State Engineer reported that the Bureau's devclopment "is essentially a single-purpose power project." Id. at 44 .

36 In argument before the Federal Power Commission on rehearing, the Bureau cited three projects which it claimed Congress has authorized solcly for power development (Tr. 1508). These were:

(1) Davis Dam on the Colorado River, which is shown by the report of the Secretary of the Interior to Congress to be a multipurpose dam. H. R. Doc. No. 186, 77th Cong., 1st Sess. 1, 3 (1941);

(2) Kortes Dam, which the Bureau of Reclamation Project Planning Report declares to be one of 90 flood control dams in the Missouri River basim. SEN. Doc. No. 191, 78th Cong., 2d Sess. 21, 22, 24 (1944);

(3) Heart Mountain project, which is shown by the report of the Secretary of the Interior to Congress to be a 5,000-kilowatt power plant installed on an irrigation conduit leading from the Shoshone Dam in Wyoming. H. R. Doc. No. 281, 79th Cong., 1st Sess. vi, xi (1945).

In each of these cases it is apparent that Congress authorized the generation of power only as an incident to the operation of flood control or reclamation works. 
Kings River power is not needed for pumping on the Central Valley project. ${ }^{37}$ Shasta and Keswick plants will generate annually an average of about 1.8 billion kilowatt-hours. The Bureau estimates that the combined irrigation pumping requirements of the Central Valley and the proposed San Luis-West Side projects will reach only about three-quarters of a billion kilowatt-hours by 1976 . Thus Shasta and Keswick plants can now supply two and one half times the total irrigation pumping load envisioned by the Bureau twenty-five years hence.

The Bureau's development would be a financial burden-not a benefit-to the Central Valley project. ${ }^{38}$ Annual power revenues would be $\$ 1,980,000$ less than annual costs. ${ }^{30}$ Water users in the Central Valley would be called upon to subsidize the Bureau's power venture on Kings River. If the Kings River project were added to the Central Valley project the Bureau would increase the repayment obligation of water users by " $\$ 13,446,000$ without any additional water being made available." 40

Prevention of private development of Kings River would cost the national economy many millions of dollars in unrecovered taxes and undeveloped hydroelectric power. Construction of the Company's project would provide a large tax revenue to local, state and federal governments. Tax payments to Fresno County alone would exceed $\$ 1,000,000$ per year; state and federal taxes would equal another $\$ 1,400,000$ annually. Construction of the smaller Bureau develop-

37 The Federal Power Commission found that "the Bureau of Reclamation has available from its large power installation at the Shasta Dam sufficient power for its own requirements in connection with the Central Valley Project." Opinion No. 183, p. 12. The California State Engineer reached the same conclusion, saying: "Studies of the Division of Water Resources indicate that an adequate supply of electric power would be available from the Central Valley project to meet the power demands of that project and also furnish power for project pumping on the proposed San Luis-West Side project if the latter project is authorized and constructed." H.R. Doc. No. 537, 81st Cong., $2 d$ Sess. 47 (1950).

38 The Federal Power Commission staff declared: "According to the Secretary's own figures showing costs in excess of revenues, the Kings River developinent as presently proposed would, if added to the Central Valley Project, be a financial burden instead of an asset to that Project" (Reply Brief on Rehearing, p. 29).

${ }^{39}$ State Engineer's Report. H. R. Doc. No. 537, 81st Cong., 2d Sess. 46 (1950).

$40 \mathrm{Id}$. at 14 . To provide revenues in excess of the costs estimated by the Bureau, the State found that Kings River power must be sold wholesale at " 8 mills or more per kilowatt-hour." H. R. Doc. No. 537, 81st Cong., 2d Sess. 11 (1950). The Company's wholesale power rate to its 12 municipal customers averaged only 6.1 mills per kilowatt-hour in 1949, and even its retail rate for irrigation pumping to many farmers in the San Joaquin Valley was less than 7 mills. 
ment would result in a further large economic loss. The Federal Power Commission Staff, evaluating this loss, said:

The value of the larger development proposed by the company is $\$ 4,500,000$ more per year than the value of the development proposed by the Secretary, although the investment in each case was given as substantially the same. Over the 61-year repayment period proposed by the Secretary, the difference would aggregate $\$ 270,000,000.41$

\section{It further stated:}

The Commission should not allow the complete loss of power worth $\$ 270,000,000$ or more when that power can be developed by the power company and sold at rates controlled by the State of California. ${ }^{42}$

Where, as here, local agencies are able and willing fully to develop power resources, there is no justification for the expenditure of federal funds for that purpose. Congress has recognized this and long ago adopted the policy that single-purpose power projects, such as those on upper Kings River, should be authorized for construction and operation under Federal Power Commission license pursuant to the provisions of the Federal Water Power Act. ${ }^{43}$ This act, passed in 1920 and reenacted in 1935 as Part I of the Federal Power Act, was designed to encourage the rapid development of the nation's water resources by local agencies under conditions which provide every safeguard that Congress thought necessary for the protection and promotion of the public welfare.

41 Reply Brief on Rehearing, p. 31.

42 Id. at 48.

4341 STar. 1063 (1920), as amended, 16 U.S.C. \$ 791 (1946).

44 The House Committee on Water Power, reporting the bill which became the Federal Water Power Act, said:

"... the theory of the' substitute [bill] which is herewith reported is to provide for the development of hydroelectric power by private capital." H. R. REP. No. 715, 65th Cong., 2d Sess. 15 (1918).

The Senate Committee on Commerce in its report on the bill stated:

"Every year that our water powers are undeveloped means a loss to the people in one form or another, almost, if not quite, equal to the cost of their development. Legislative action should be delayed no longer. We should do one of two things: We should pass legislation which will lead private capital and enterprise to develop these resources under such regulations as will give consumers good service and cheap power, or the Government itself should proceed to make this development. This bill proceeds on the theory of private development with ultimate public ownership possible." SEN. REP. No. 180, 66th Cong., Ist Sess. 3 (1919). 
COORDINATION, NOT DUPLICATION

Pacific Gas and Electric Company recognizes fully the desirability of conserving and putting to greatest beneficial use the waters of California. The Company has shown its willingness to cooperate wholeheartedly with federal and state governments, and with local interests, in the development of sound water projects.

Coordination of Central Valley project power sources with existing local facilities will provide maximum financial assistance to the project's vitally needed water conservation works. The Company's cooperative program renders unnecessary the loss of millions of dollars involved in the Bureau's duplication of transmission and steamelectric generating facilities. Federal funds should not be diverted from construction of water features of the project in order to transform it into a commercial power enterprise to the detriment of water users, taxpayers and power consumers. 